$\S=-1$

\title{
Ranking the Factors that Influence the Construction Project Success: the Jordanian Perspective
}

\author{
Ghanim A. Bakr ${ }^{1}$ \\ ${ }^{\text {I}}$ Civil Engineering Dept/Zarqa University, Zarqa, Jordan, ghbekr@zu.edu.jo
}

\begin{abstract}
Project success is what must be done for the project to be acceptable to the client, stakeholders and end-users who will be affected by the project. The study of project success and the critical success factors (CSFs) are the means adopted to improve the effectiveness of project.

This research is conducted in an effort to identify which factors influence the success of project accomplishment in Jordan. This study has selected, through an extensive literature review and interviews, (83) factors categorized into (7) main groups that the questionnaire respondents were required to score. The responses from 66 professionals with an average of 15 years of experience in different types of construction projects in Jordan were collected and analyzed using SPSS and the most important factors for success for various success criteria are presented depending on the relative importance index to rank the categories. The research revealed the significant groups of factors are: factors related to Client, factors related to Contractor's, factors related to Project Manager (PM), and factors related to Project management. In addition the top ten sub factors are: Assertion of the client towards short time of the project, availability of skilled labor, Assertion of the client towards high level of the quality, capability of the client in taking risk, previous experience of the PM in similar projects, previous experience of the contractor in similar projects, decision making by the client/ the client's representative at the right time, assertion of client towards low cost of project, experience in project management in previous projects, and flow of the information among parties. The findings of this study might be useful to construction project participants in taking decisions leading to successful finishing of construction projects in Jordan.
\end{abstract}

Keywords: Construction projects, Critical success factors, Jordan, project success.

\section{Introduction}

Construction companies and project managers, in an increasing range of complication of business, experience different challenges and practices. They need to administer their projects efficiently. They need high level management of information system that can supply precise knowledge to enable the project managers to take the suitable job when they experience problems.

One of the techniques that provide essential information is "Critical Success Factors - CSFs" technique. The concept CSF was initially presented in 1961 and advised that companies should focus on their significant information concerning this issue to achieve efficient management [1]. In addition, it was specified that there was insufficiency of information needed for decision making or measurement of information.

Also, the issue of information management could disrupt the business as the company should present a plan for control of design and policy for management that can submit specific knowledge for any project and the industry as a whole [2]. The system of CSF can assist in defining significant information required by the different levels of management [3]. In general, this system can assist in improving the level of performance at the different stages of the project (design, construction, and maintenance).

\section{Objectives of the Research}

The objectives of the research are to identify the major and minor (primary and secondary) critical success factors that can affect the overall performance of contractors during the implementing con- struction projects in Jordan. In particular, these objectives can be listed below:

- To realize the minor and major CSFs that has significant effects on construction contractors in Jordan.

- To provide a better understanding of the CSFs that influences the failure or success of the projects at the different phases of the construction projects.

\section{Literature Review}

\subsection{Definition of Critical Success Factors}

The expression "Critical Success Factors - CSF" was defined by many researchers. CSFs are the fields the project managers should consider [4]. These factors may affect positively or negatively the internal and external environment of the organization. They can be recognized by assessment of the strategy, environment and operations. If the features are sustained, the situation is maintained, or the parameters are successful. It may strength the capacity of the organization with respect to the competition in its specific industry [5]. It was stated that the manager may focus, constantly, to those managerial matters to fulfill considerable level of accomplishment [6]. Those matters are fundamental for both current jobs and future prosperity of the organization.

The expression CSFs can also be expressed as the vital aspects that can lead to establishment success as they provide the information required for present activities and future success [7]. 


\subsection{The Nature of CSFs}

Generally, the CSFs are connected with four operations within any organization. These are planning techniques, job quality, management information system, and market characteristics [8].The management information system is related to utilization of CSFs in this system. To realize the manager's requirements with respect to information, CSFs should be inclusive in the system. The CSFs have to be applied in the training process for managerial personnel who work on improving strategies that could assist the establishment to work out their strategies. They have to guarantee that managerial staff should recognize a list of CSFs and focus on those specific areas that may modify strategy formation.

\subsection{The Significance of Critical Success Factors}

The CSFs provide important information for managers and allow them to focus on short list of activities. The function of CSFs is to help the establishment to plan their strategies. Also objectives and goals are to strengthen the effectiveness of communications with various levels in company and to help in improving the information system [9]. Through a study, [6] it was confirmed the importance of having a brief list of CSFs and declared that managers had to provide a continuous concentration on those necessary measures until aims were successfully achieved. In other words, if accomplishments of those CSFs matters are not enough, the performance of the establishment will not be as expected. On the other hand, when activities recognized by CSFs perform in a perfect manner, the organization will outperform its competition [10].

\subsection{Employing the Critical Success Factors}

The fundamental implementation of CSFs concept is to help establishing the management information system. The essential goal of this system is providing information to realize the level management's needs and encourage communications between various levels of the establishment's management. The CSFs are found to help understanding the important areas that should receive more concentration and provide measures that will assist in those areas [11]. The CSFs concept provides information to help an establishment in planning future strategy. Different planning operations require future level of CSFs. The CSFs supply information on standards concerning project success by examining many aspects and measures with respect to finishing duration, guidance and connection [3]. Another significant application of CSFs concepts is to provide important information to all managers for their needs.

\subsection{Previous Research Work in Critical Success Factors}

As mentioned before, Daniel, was among the pioneer specialists who presented the CSFs as job directing for the first time in 1961. In his view there are as many as 3 to 6 CSFs which set the success in all business types. Among the next specialist, Rockart Participated in the area of presenting the CSFs more than other specialists [12]. In the construction field, a study [13] presented seven factors as the success factors. These are jobs programming, planning of design activities, commitments to project's goals, team motivation, technical efficiency of the project manager, control process, definition of jobs and its scope. The recognition between success standards and success factors is also significant. The success ideas are the degree on which the project failure or success is examined, while the factors of success are those associated into the management system and outcome the project success indirectly or directly [14]. Other researchers [15] presented a project model and ten defined factors. These are project function, scheduling, technical activities, user consultant, user opinion, feedbacks statements, lines of communications, and wrong detection top management backup, and staffing and training.
The critical success factors can also be divided into four main groups in a new structure [16]. These are project related factors, project manager and team members related factors, and external related factors. Another research [17] considered the following groups: customer's effects, commercial success, project output, and beneficiary related group. Also [18] identified five groups of factors. These are: expert project manager, availability of financial resources during the project duration, qualified project team, obligation to the project, and availability of other resources.

Recently in Sirilanka, a study considered 46 factors grouped under 10 main groups. In addition, 13 major incentives which could be applied to upgrade the efficiency of the construction industry were presented [19]. Another study in the same country considered 30 CSFs which affect the success of construction projects. The study has concentrated on controllable factors from all participants (clients, consultants, and contractors) views. The success factors were categorized under the three traditional criteria's: time, cost, and quality [20]. Similar study in India has considered 36 success factors for public construction projects categorized under 5 groups. The shortage of this study is that only the engineers employed by the public sectors were considered [21]. In Malaysia, study carried out considered 15 factors as most significant CSFs related to construction projects. The results of the study recommended a powerful consistency in understandings among the participants in meeting the importance of factors related to human reasons such as efficiency, commitment, communication and collaboration in respect to the success of construction projects. The authors suggested that more assurance should be given on improving the factors related to human matters in order to guarantee the successful execution of future projects [22].

In 2013, three papers were cited. The first presented 21 CSFs and 9 Project Success Criteria's PSCs. The study showed that less attention was given on investigating relative importance of Project Success Factors PSC. Furthermore, the researchers concluded the interest appeared to be in investigating PSFs and PSC, rather than finding which are substantial and in what manner PSFs infact affect PSC and to what extent [23]. The second developed a model with 71 factors for construction projects in Lithuania. These factors were allocated into seven main groups [24]. The third was carried out in Vietnam. This study considered twenty factors leading to the failure of construction projects in this country. These are allocated into four groups. This study revealed that, despite the changes occurred in this industry for about 10 years. The same critical factors as recognized from eight studies are still the same, also the most recognized problem leading to construction projects are issues related to Project management items.

Another study carried out to find the relationship between CSFs and performance of project. A conceptual framework was established by selecting five variables for the success of project in specific project management behavior, project operations, human factors, external factors and project related factors from contractor's point of view for Norwegian construction industry. A qualitative research with large sample was conducted [26].

\section{Methodology of the Study}

\subsection{The Questionnaire}

To achieve the goals of the study, the following three steps were carried out. The first is recognizing and grouping the CSFs gathered through the literature review. The second is the validation of the proposed questions revealed out of the interviews conducted with top management expertise. The third step is finalizing the questionnaire inlaying on feedback from the professionals and experts. The questionnaire consisted of two main sections. The first one included questions related to the participant's information (position in company or project, number of years of experience, etc.), the organization information (types of projects executed 
previously executed by the company, year in the market, number of personnel, annual volume of work, etc.).

The second part of the questionnaire contains the major and minor CSFs that have effect on the construction process. List of the major CSFs and number of minor (sub factors) included in the survey are shown in table 1 below:

Table 1:Main CSFs and sub-Factors

\begin{tabular}{|c|l|c|}
\hline CSF & \multicolumn{1}{|c|}{ Details } & $\begin{array}{c}\text { No. of sub- } \\
\text { factors }\end{array}$ \\
\hline CSF1 & Project manager (PM) related factors & 10 \\
\hline CSF2 & Factors related to the Client & 17 \\
\hline CSF3 & Factors related to Design/ Consultant & 7 \\
\hline CSF4 & Factors related to Contractor & 8 \\
\hline CSF5 & Factors related to Project management & 6 \\
\hline CSF6 & $\begin{array}{l}\text { Factors related to management of Procure- } \\
\text { ment process }\end{array}$ & 14 \\
\hline CSF7 & $\begin{array}{l}\text { Factors related to Business and environment } \\
\text { of work }\end{array}$ & 83 \\
\hline Total &
\end{tabular}

The participants engaged in the survey were requested to assess the level of impact of each sub factors on the success of the construction project. The scale of measurement of each variable is specified as those five levels of measurement of scale [27].

The data obtained from the questionnaire survey were analyzed using the Statistical Package for the Social Sciences (SPSS 17.02). Answers, from respondents for all items were entered in SPSS and identification codes were selected with their scales of measurement.

Relative importance index (RII) has been selected in this study with the objective of it providing superior perception of individual predictors and their single role amongst a given set [28]. This process has been implemented in different project management literature such as [29] [30]. The formula for the computation is presented in equation 1 below:

$\mathrm{RII}=\frac{\sum \mathrm{WX}_{\mathrm{i}}}{\mathrm{AN}}$

Where $\mathrm{W}$ is the selected weigh to each variable - according to participant's answer. This is ranges from 1 to 5 where 1 is "strongly disagree" and 5 is "strongly agree".

$\mathrm{X}$ is the frequency of each answer.

$\mathrm{A}$ is the highest possible weight for that response is 5 in this particular case.

$\mathrm{N}$ is the number of respondents

\subsection{Reliability}

Table 4: Statistical Analysis for Composite Variables

\begin{tabular}{|c|c|c|c|c|c|c|c|}
\hline CSF. & Mean & Med. & Var. & $\begin{array}{c}\text { St. } \\
\text { dev. }\end{array}$ & $\begin{array}{c}\text { Min. } \\
\text { value }\end{array}$ & $\begin{array}{c}\text { Max. } \\
\text { value }\end{array}$ & Rank \\
\hline CSF1 & 3.775 & 3.825 & 0.386 & 0.621 & 2.82 & 5.0 & 3 \\
\hline CSF2 & 4.012 & 4.134 & 0.364 & 0.603 & 2.75 & 5.0 & 1 \\
\hline CSF3 & 3.315 & 3.225 & 0.391 & 0.625 & 1.96 & 5.0 & 6 \\
\hline CSF4 & 3.951 & 4.003 & 0.420 & 0.648 & 2.36 & 5.0 & 2 \\
\hline CSF5 & 3.664 & 3.588 & 0.501 & 0.708 & 2.34 & 5.0 & 4 \\
\hline CSF6 & 3.149 & 3.213 & 0.339 & 0.582 & 1.85 & 5.0 & 7 \\
\hline CSF7 & 3.364 & 3.312 & 0.398 & 0.631 & 2.38 & 5.0 & 5 \\
\hline
\end{tabular}

To measure the internal consistency of the questionnaire Cronbach alpha was used. The coefficient alpha extent in value from 0 to 1.00 [31]. Acceptable reliability will be when the value of coefficient alpha is greater than 0.70 while 0.80 mark good level of reliability, and excellent reliability will be indicated when the Cronbach alpha in more than 0.90 [32] [33] [34]. For this research, the above criteria were adopted. Accordingly, the subfactors will be reflected when it fails in the test of reliability. The results of Cronbach alpha for the CSFs include in the survey are shown in table 2 .

\begin{tabular}{|l|l|c|}
\multicolumn{1}{|c}{ Table 2: Reliability Composite variable Test } \\
\hline $\begin{array}{c}\text { Critical } \\
\text { Success } \\
\text { Factor. }\end{array}$ & \multicolumn{1}{|c|}{ Details } & $\begin{array}{c}\text { Cronbach's } \\
\text { alpha }\end{array}$ \\
\hline CSF1 & Project manager (PM) related factors & 0.724 \\
\hline CSF2 & Factors related to the Client & 0.845 \\
\hline CSF3 & Factors related to Design/ Consultant & 0.716 \\
\hline CSF4 & Factors related to Contractor & 0.813 \\
\hline CSF5 & Factors related to Project management & 0.755 \\
\hline CSF6 & $\begin{array}{l}\text { Factors related to management of Procure- } \\
\text { ment process }\end{array}$ & 0.682 \\
\hline CSF7 & $\begin{array}{l}\text { Factors related to Business and environment } \\
\text { of work }\end{array}$ & 0.656 \\
\hline
\end{tabular}

Table 2 shows composite variable CSFs and CSF4 were found to acceptable standard of reliability, while composite variable CSF1, CSF3 and CSF5 showed acceptable levels of reliability. The CSF6 and CSF7 result lower criterion of 0.70. Some researchers indicated that lower limit in exploratory studies could be adopted and 0.60 was applied as a minimum criterion. According to this criterion it is assumed that all seven composite variables present acceptable level of internal consistency and uniformity [35] [36].

\section{Results of the Study}

The questionnaire was delivered and collected in person. These were distributed to 150 participants in Jordan out of which 58 responded. The number of questionnaire sets delivered and number received are shown in table 3 .

Table 3: Number of Questionnaire Distributed - Received

\begin{tabular}{|l|c|c|c|}
\hline \multicolumn{1}{|c|}{ Respondents } & $\begin{array}{c}\text { No. distrib- } \\
\text { uted }\end{array}$ & $\begin{array}{c}\text { No. re- } \\
\text { ceived }\end{array}$ & $\begin{array}{c}\text { Percentage of } \\
\text { response }\end{array}$ \\
\hline Clients/Owners & 35 & 22 & $62.8 \%$ \\
\hline Consultants/Designers & 35 & 24 & $68.6 \%$ \\
\hline $\begin{array}{l}\text { Contractors/Sub- } \\
\text { Contractors }\end{array}$ & 35 & 20 & $57.1 \%$ \\
\hline Total & 105 & 66 & $62.8 \%$ \\
\hline
\end{tabular}

\subsection{The Respondent's Characteristics}

As mentioned in table 3, 66 questionnaire sets were received. Around $63 \%$ were clients/owners, $69 \%$ consultants/designers and $63 \%$ contractors/subcontractors. More than $72 \%$ of the respondents have experience of in the construction industry of more than 15 years. The study covered both public sector and private sector. The participants representing clients are from different ministries and municipalities. On the other hand, contracting companies included from highest two classes (first and second). The experience of the respondents covered different types of projects - housing, public buildings, hospitals, water supply projects, water treatment plants, etc.

\subsection{Statistical analysis for composite variable}

For integral scale variables, the arithmetic deviations are commonly adopted. Table 4 shows briefly the analysis of data for each critical success factor. 
All the seven variables included in table 4 had minimum score ranges from 1.85 to 2.82 , while the maximum score was 5.00 . The mean for each single CSF was obtained on a basis of the main components analysis. In order to establish the CSFs for each variable, the technique of mean score ranking was adopted. Accordingly, the mean scores of those seven new composites variables were elaborated. For example CSF2 (client related factors) was calculated from variables of all its sub-factors to represent the mentioned concept. The ranking of the seven CSFs was specified by their arithmetic mean scores [37] [38]. Table 5 shows ranking of critical success factors. (Note: The significant CSFs are the shaded ones).

Table 5: Ranking of the Critical Success Factors

\begin{tabular}{|c|l|c|}
\hline Rank & Critical Success Factor - overall average RII = 3.659 & $\begin{array}{l}\text { Mean } \\
\text { Score }\end{array}$ \\
\hline 1 & CSF2 Client related factors & $\mathbf{4 . 0 1 2}$ \\
\hline 2 & CSF4 Contractor's related factors & $\mathbf{3 . 9 5 1}$ \\
\hline 3 & CSF1 Project manager (PM) related factors & $\mathbf{3 . 7 7 5}$ \\
\hline 4 & CSF5 Project management related factors & $\mathbf{3 . 6 6 4}$ \\
\hline 5 & CSF7 Business and work environment related factors & 3.334 \\
\hline 6 & CSF3 Design/ Consultant related factors & 3.315 \\
\hline 7 & CSF6 Procurement management related factors & 3.149 \\
\hline
\end{tabular}

\subsection{Ranking of the Critical Success Sub-factors}

With their ranking details of the scores of all the sub-factors together included in the survey are shown in tables 6-12.

Table 6: CSF1 Project Manager (PM) related Factors

\begin{tabular}{|c|l|c|c|}
\hline $\begin{array}{c}\text { Sub- } \\
\text { factor } \\
\text { no. }\end{array}$ & \multicolumn{1}{|c|}{ Sub-factor - Average RII = 3.775 } & Mean & Rank \\
\hline 1 & $\begin{array}{l}\text { Previous experience of the PM in similar } \\
\text { projects }\end{array}$ & 4.123 & 1 \\
\hline 2 & $\begin{array}{l}\text { Technical and managerial capability of the } \\
\text { PM }\end{array}$ & 3.822 & 4 \\
\hline 3 & $\begin{array}{l}\text { Efficiency of the PM in solving day-to-day } \\
\text { problems }\end{array}$ & 3.654 & 9 \\
\hline 4 & $\begin{array}{l}\text { The PM power to take financial decisions } \\
\text { The expertise of The PM concerning leader- } \\
\text { ship }\end{array}$ & 3.789 & 7 \\
\hline 6 & $\begin{array}{l}\text { The expertise of The PM concerning organi- } \\
\text { zation }\end{array}$ & 3.854 & 3 \\
\hline 7 & $\begin{array}{l}\text { The expertise of The PM to deal with sub- } \\
\text { contractors }\end{array}$ & 3.687 & 8 \\
\hline 8 & $\begin{array}{l}\text { The coordination capability of the PM to } \\
\text { deal with the owner's representative. }\end{array}$ & 3.884 & 2 \\
\hline 9 & $\begin{array}{l}\text { The capability of the PM meet with the } \\
\text { requirements of time, cost and quality }\end{array}$ & 3.797 & 6 \\
\hline 10 & $\begin{array}{l}\text { Capability of the PM with respect to motiva- } \\
\text { tion of the staff }\end{array}$ & 3.812 & 5 \\
\hline
\end{tabular}

Table 7: CSF2 Client Related Factors

\begin{tabular}{|c|l|c|c|}
\hline $\begin{array}{c}\text { Sub- } \\
\text { factor } \\
\text { no. }\end{array}$ & \multicolumn{1}{|c|}{ Sub-factor Average RII =4.024 } & Mean & $\begin{array}{c}\text { Ra } \\
\text { nk }\end{array}$ \\
\hline 1 & $\begin{array}{l}\text { Satisfaction of the client with respect to } \\
\text { project's team }\end{array}$ & 3.921 & 14 \\
\hline 2 & $\begin{array}{l}\text { Assertion of client towards low cost of pro- } \\
\text { ject. }\end{array}$ & 4.111 & 5 \\
\hline 3 & Capability of decision making by client. & 3.912 & 15 \\
\hline 4 & Client's representative effectiveness & 3.789 & 17 \\
\hline 5 & $\begin{array}{l}\text { Previous experience of the client in similar } \\
\text { projects }\end{array}$ & 3.959 & 11 \\
\hline 6 & Sophisticated/ non-sophisticated client. & 4.022 & 8 \\
\hline 7 & $\begin{array}{l}\text { Decision making by the client/ the client's } \\
\text { representative at the right time }\end{array}$ & 4.122 & 4 \\
\hline 8 & Capability of the client in taking risk. & 4.125 & 3 \\
\hline 9 & $\begin{array}{l}\text { Assertion of the client towards high level of } \\
\text { the quality }\end{array}$ & 4.130 & 2 \\
\hline 10 & $\begin{array}{l}\text { Assertion of the client towards short time of } \\
\text { the project. }\end{array}$ & 4.211 & 1 \\
\hline 11 & Magnitude of the client's organization. & 3.892 & 16 \\
\hline 12 & Assessment of client to the project's scope & 3.954 & 12 \\
\hline & \multicolumn{2}{|l}{} \\
\hline
\end{tabular}

\begin{tabular}{|c|l|c|c|}
\hline & and objectives. & & \\
\hline 13 & $\begin{array}{l}\text { Level of client's project management } \\
\text { knowledge }\end{array}$ & 4.002 & 9 \\
\hline 14 & Kind of project - public, private, etc. & 4.065 & 7 \\
\hline 15 & $\begin{array}{l}\text { Early and continuous involvement in the } \\
\text { project development }\end{array}$ & 3.997 & 10 \\
\hline 16 & Relationship with other project stakeholders & 4.081 & 6 \\
\hline 17 & Adoption to changes in the project's plan. & 3.923 & 13 \\
\hline
\end{tabular}

Table 8: CSF3 Design/ Consultant Related Factors

\begin{tabular}{|c|l|c|c|}
\hline $\begin{array}{c}\text { Sub- } \\
\text { factor } \\
\text { no. }\end{array}$ & \multicolumn{1}{|c|}{ Sub-factor - Average RII =3.315 } & Mean & $\begin{array}{c}\text { Ra } \\
\mathrm{nk}\end{array}$ \\
\hline 1 & $\begin{array}{l}\text { Previous experience of designer with similar } \\
\text { projects }\end{array}$ & 3.124 & 7 \\
\hline 2 & Complexity of the design of the project & $\mathbf{3 . 3 2 2}$ & 4 \\
\hline 3 & Sufficiency of the contract documents. & $\mathbf{3 . 3 5 8}$ & 3 \\
\hline 4 & Production of contract documents on time & 3.287 & 6 \\
\hline 5 & $\begin{array}{l}\text { Contribution of consultant to project man- } \\
\text { agement matters. }\end{array}$ & $\mathbf{3 . 4 5 2}$ & 1 \\
\hline 6 & $\begin{array}{l}\text { Obligation of design team to time, cost and } \\
\text { quality }\end{array}$ & $\mathbf{3 . 4 1 1}$ & 2 \\
\hline 7 & $\begin{array}{l}\text { Interrelationship between design team and } \\
\text { construction team. }\end{array}$ & 3.254 & 5 \\
\hline
\end{tabular}

Table 9: CSF4 Contractor's Related Factors

\begin{tabular}{|c|l|c|c|}
\hline $\begin{array}{c}\text { Sub- } \\
\text { factor } \\
\text { no. }\end{array}$ & \multicolumn{1}{|c|}{ Sub-factor - Average RII = 3.951 } & Mean & Rank \\
\hline 1 & $\begin{array}{l}\text { Previous experience of the contractor in } \\
\text { similar projects }\end{array}$ & $\mathbf{4 . 1 2 3}$ & 2 \\
\hline 2 & Participation of the subcontractors & 3.864 & 6 \\
\hline 3 & Cash flow capability of the contractor & $\mathbf{3 . 9 5 4}$ & 4 \\
\hline 4 & Flow of the information among parties & $\mathbf{4 . 1 0 2}$ & 3 \\
\hline 5 & $\begin{array}{l}\text { Adoption of adequate time, cost and } \\
\text { quality systems by the contractor }\end{array}$ & 3.782 & 7 \\
\hline 6 & Availability of skilled labour & $\mathbf{4 . 1 9 7}$ & 1 \\
\hline 7 & $\begin{array}{l}\text { Providing training program to the work- } \\
\text { ers }\end{array}$ & 3.725 & 8 \\
\hline 8 & $\begin{array}{l}\text { Providing safety appliances to the } \\
\text { workers. }\end{array}$ & 3.865 & 5 \\
\hline
\end{tabular}

Table 10: CSF5 Project Management Related Factors

\begin{tabular}{|c|c|c|c|}
\hline $\begin{array}{c}\text { Sub- } \\
\text { factor } \\
\text { no. }\end{array}$ & Sub-factor - Average RII = 3.664 & Mean & Rank \\
\hline 1 & Adoption of efficient safety scheme & 3.125 & 21 \\
\hline 2 & $\begin{array}{l}\text { Adoption of efficient quality assurance } \\
\text { scheme }\end{array}$ & 3.789 & 4 \\
\hline 3 & $\begin{array}{l}\text { Experience in project management in pre- } \\
\text { vious projects }\end{array}$ & 4.105 & 1 \\
\hline 4 & Level of environmental management & 3.697 & 10 \\
\hline 5 & Solving of disputes efficiently & 3.847 & 3 \\
\hline 6 & Application of motivation schemes & 3.258 & 20 \\
\hline 7 & Program of communication adopted. & 3.645 & 15 \\
\hline 8 & $\begin{array}{l}\text { Control techniques implemented into the } \\
\text { project. }\end{array}$ & 3.687 & 13 \\
\hline 9 & Planning capabilities of the project's staff. & 3.521 & 18 \\
\hline 10 & Efficiency of coordination among parties. & 3.789 & 5 \\
\hline 11 & Efficiency towards decision making. & 3.632 & 16 \\
\hline 12 & $\begin{array}{l}\text { Monitoring of project during different } \\
\text { phases. }\end{array}$ & 3.878 & 2 \\
\hline 13 & $\begin{array}{l}\text { The capability of improving the convenient } \\
\text { organization structure. }\end{array}$ & 3.698 & 9 \\
\hline 14 & $\begin{array}{l}\text { Supervision and monitoring of sub- } \\
\text { contractor's work. }\end{array}$ & 3.694 & 11 \\
\hline 15 & Efficiency of feedback procedures & 3.778 & 7 \\
\hline 16 & Risk management system & 3.666 & 14 \\
\hline 17 & Management of contract & 3.478 & 19 \\
\hline 18 & Effective allocation of man-power & 3.789 & 6 \\
\hline 19 & Size represented by the value of the project. & 3.694 & 12 \\
\hline 20 & The degree of project's complexity & 3.587 & 17 \\
\hline 21 & Possibility of meeting project deadline. & 3.745 & 7 \\
\hline
\end{tabular}


Table 11: CSF6 Procurement Management Related Factors

\begin{tabular}{|c|l|c|c|}
\hline $\begin{array}{c}\text { Sub- } \\
\text { factor } \\
\text { no. }\end{array}$ & \multicolumn{1}{|c|}{ Sub-factor - Average RII = 3.149 } & Mean & Rank \\
\hline 1 & $\begin{array}{l}\text { Selection of the design and construction } \\
\text { teams }\end{array}$ & $\mathbf{3 . 2 2 5}$ & 2 \\
\hline 2 & $\begin{array}{l}\text { Competitive procurement and tendering } \\
\text { method }\end{array}$ & $\mathbf{3 . 4 5 0}$ & 1 \\
\hline 3 & $\begin{array}{l}\text { Contract type (lump sum, unit price, cost } \\
\text { plus, etc. })\end{array}$ & 3.012 & 5 \\
\hline 4 & Selection of sub-contractors & 3.112 & 3 \\
\hline 5 & Selection of suppliers & 2.988 & 6 \\
\hline 6 & Transparency in the procurement process & 3.111 & 4 \\
\hline
\end{tabular}

Table 12: CSF7 Business and Work Environment Related Factors

\begin{tabular}{|c|l|c|c|}
\hline $\begin{array}{c}\text { Success- } \\
\text { factor } \\
\text { no. }\end{array}$ & Sub-factor - Average RII = 3.364 & Mean & Rank \\
\hline 1 & Economic environment & 3.124 & 13 \\
\hline 2 & Social environment & 3.145 & 12 \\
\hline 3 & Political environment & $\mathbf{3 . 4 5 5}$ & 7 \\
\hline 4 & Physical work environment & 3.264 & 8 \\
\hline 5 & Industrial relationship & 3.058 & 14 \\
\hline 6 & Commitment of all parties to the project & $\mathbf{3 . 4 7 8}$ & 4 \\
\hline 7 & Adequacy of funding & 3.154 & 11 \\
\hline 8 & Technology availability & 3.222 & 10 \\
\hline 9 & Human skill availability & $\mathbf{3 . 4 7 7}$ & 5 \\
\hline 10 & Disingenuous practices & $\mathbf{3 . 7 8 4}$ & 1 \\
\hline 11 & $\begin{array}{l}\text { Relationship with government depart- } \\
\text { ments }\end{array}$ & $\mathbf{3 . 4 5 6}$ & 6 \\
\hline 12 & Relationship with local community & $\mathbf{3 . 6 5 4}$ & 2 \\
\hline 13 & Availability of resources & $\mathbf{3 . 5 8 9}$ & 3 \\
\hline 14 & Weather conditions. & 3.235 & 9 \\
\hline
\end{tabular}

\section{Conclusions}

A survey base on questionnaire was utilized to formulate the attitude of project participants towards "Critical Success factors affecting the outcomes of construction projects in Jordan. A total of 105 questionnaire set were distributed and collected by person, in different municipalities, 66 set were collected with a percentage $63 \%$. The participants involve in the study were asked to point out the level of significance of 83 factors distributed over seven groups. The significant factors within each group were selected as those with RII over the average RIIs for each group. The analysis of the survey results revealed the following:

1. The significant critical success factors are:

- $\quad$ CSF2: Client related factors with average RII = 4.012

- CSF4 Contractor's related factors with average RII $=3.951$

- CSF1 Project manager (PM) related factors with average RII $=3.775$

- CSF5 Project management related factors with average $\mathrm{RII}=3.664$

2. Top ten among the 83 sub-factors are:

- Assertion of the client towards short time of the project with $\mathrm{RII}=4.211$

- $\quad$ Availability of skilled labor with RII $=4.197$

- Assertion of the client towards high level of the quality with RII $=4.130$

- $\quad$ Capability of the client in taking risk with RII = 4.125

- Previous experience of the PM in similar projects with RII $=4.123$

- Previous experience of the contractor in similar projects with $\mathrm{RII}=4.123$

- Decision making by the client/ the client's representative at the right time with $\mathrm{RII}=4.122$

- Assertion of client towards low cost of project with $\mathrm{RII}=4.111$
- Experience in project management in previous projects with $\mathrm{RII}=4.105$

- $\quad$ Flow of the information among parties with RII = 4.102

3. Taking into consideration that average RII among the 83 sub-factors is 3.600 , number of significant factors for each group are the following:

CSF1 - Project manager (PM) related factors - 7 out of 10 factors

CSF2 - Client related factors - 7 out of 17 factors

CSF3 - Design/ Consultant related factors -4 out of 7 factors

CSF4 - Contractor's related factors - 4 out of 8 factors

CSF5 - Project management related factors -13 out of 21 factors

CSF6 - Procurement management related factors -2 out of 6 factors

CSF7 - Business and work environment related factors 7 out of 14 factors.

\section{References}

[1] Anthony RN, Dearden J, and Vancil RF, “ Key economic variables: Management Control Systems", Homewood, IL: Irwin, 1972

[2] Ramaprasad A, William J, and Daniel DR, "Management information crisis", Harvard Business Review, 39(5), 1961, 111-21.

[3] Ramaprasad A, and William J. "The utilization of critical success factors: A profile", 29th Annual Meeting of the Decision Science Institute, Las Vegas, NV, USA, 1998.

[4] Ferguson CR, and Dickinson R, "Critical success factors for directors in the eighties", Business Horizons, 1982, 25(3), 14-8.

[5] Leidecker J, and Bruno A, 1984 "Identifying and using critical success factors", Long Range Planning, 17(1), 23-32.

[6] Khandelwal V, and Ferguson J, "Critical success factors and the growth of IT in selected geographic regions". Proceedings of the 32nd Hawaii International Conference on System Sciences - 1999, Maui, HI, USA.

[7] Van Veen-Dirks P, and M. Wijin, "Strategic control:

Meshing critical factors with the balanced scorecard" Long Range Planning, 2002, 35(4), 407-27.

[8] Grunert KG, and Ellegaard, C., "The concept of key success factors: Theory and method", MAPP working paper No.4, October 1992.

[9] Bullen CV, and Rockart JF, “A primer on critical success factors, CISR No. 69, Sloan WP No. 1220-81”, Centre for Information System Research, Sloan School of Management, Massachusetts Institute of Technology, 1981.

[10] Vasconcellos E, "The impact of key success factors on company performance", Long Range Planning, 1988, 21(6), 56-64.

[11] Boynlon AC, and Zmud RW, "An assessment of critical success factors", MIT Sloan Management Review, 1984, 25(4), 17-27.

[12] Rockart JF, "The changing role of the information systems executive: a critical success factors perspective", Massachusetts Institute of Technology Boston, 1982, p.2.

[13] Ashley DB, "New trends in risk management", paper presented at the internet's 10th International Expert Seminar on New Approaches in Project Management, Zurich, 1986, 10-12 March.

[14] Pinto JK, Mantel J, 1990, "The causes of project failure" . IEEE Transactions on Engineering Management, 37 (4), 269-277

[15] Pinto JK, and Slevin DP, "Critical success factors across the project life cycle" , Project Management Journal, 1988, 19 (3). p. $67-$ 75 .

[16] Belassi W, and Tukel O, "A new framework for determining critical success/failure factors in projects.' Int. J. Proj. Manage., 14(3), 1996, 141-151.

[17] Kenny J, "Effective project management for strategic innovation and change in organizational context", Project Management Journal, 2003, 34(1), 43-53

[18] Nguyen LD, Ogunlana S, and Lan D, "A study on project Success factors in large construction projects in Vietnam", Engineering, Construction and Architectural Management, Vol. 11 No. 6, pp. 404-413. 8, 2004

[19] De Silva N, Rajakaruna R, and Bandara K "Challenges faced by the construction industry in Sri Lanka: perspective of clients and contractors". Available from http://usir.salford.ac.uk, 2008 
[20] Kenny, J. "Effective project management for strategic innovation and change in organizational context", Project Management Jour nal, 2003, 34(1), 43-53.

[21] Tabish S, and Jha K, "Important factors for success of public construction projects" In 2nd International Conference on Construction and Project Management IPEDR. Singapore: IACSIT Press. 2011 ,

[22] Yong Y, and N. Mustaffa, N. "Analysis of factors critical to construction project success in Malaysia", Engineering, Construction and Architectural Management, 2012, 19(5), 543-556.

[23] Gunasekera H, "Managing critical factors in construction projects: applicability of compensatory model for effective project management" (Doctoral dissertation, Sri Jayewardenepura University). 2009 ,

[24] Gudiene, N, Banaitis, A, Podvezko, V \& Banaitiene, N, "Identification and evaluation of the critical success factors for construction projects in Lithuania: AHP approach" . Journal of Civil Engineering and Management, 2014, pp.350-59.

[25] Nguyen, TP. \& Chileshe, N, "Revisiting the critical factors causing failure of construction projects in Vietnam". In 29th Annual ARCOM Conference. 2nd to 4th September 2013. UK. p. 929 938.5

[26] Zidane Y, Johansen A, Andersen B, and Hoseini, E "Timethieves and bottlenecks in the Norwegian construction projects", Procedia Economics and Fiancé. 2015, 21. p. 486-493.

[27] Likert R, "A technique for the measurement of attitudes", Archives of Psychology, 1932, 140, 1-55.

[28] Tonidandel, S and LeBreton JM, "Relative importance analysis: A useful supplement to regression analysis", Journal of Business and Psychology, 2011, pp.1-9.

[29] Gudiene N, Banaitis A, and Banaitienne N, "Evaluation of critical success factors for construction projects - an empirical study in Lithuania", International journal of strategic property management, 2013, 7, pp.21-31.

[30] Iyer K, and Jha K, "Factors affecting cost performance: evidence from Indian construction projects", International journal of project management, 2006, 8, pp.283-357.

[31] Cronbach LJ, "Coefficient alpha and the internal structure of tests", Psychometrika, 1951, 16(3), 93-6.

[32] Nunnally J, "Psychometric theory" , New York: McGraw-Hill. 1979 ,

[33] Peter JP, "Reliability: A review of psychometric basics and recent marketing practices", Journal of Marketing Research, 1979, 16(1), 6-17.

[34] Robinson JP, Shaver PR, and Wrightsman LS, "Criteria for scale selection and evaluation", In measures of personality and social psychological attitudes, San Diego, CA: Academic Press, 1991.

[35] Ng, TS and Tang, Z "Labour-intensive construction subcontractors: Their critical success factors, International Journal of project management, 2010, 28(7), 732-40.

[36] Cheung E, Chan AP, and Kajewswi S, "Factors contributing to successful public private partnership projects, comparing Hong Kong with Australia and the United Kingdom", Journal of Facilities Management, 2012, 10(1), 45-58. 